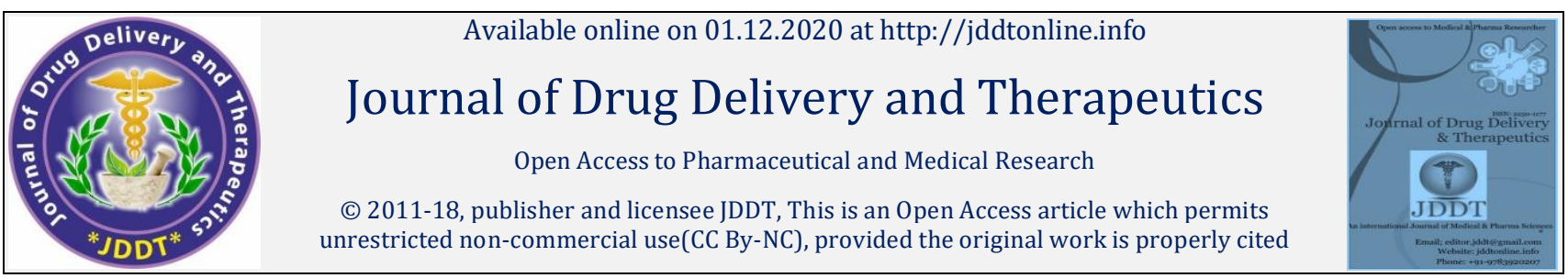

Open $\odot$ Access

Research Article

\title{
Synthesis, spectroscopic characterization and biological application of copper complex of 5-carbethoxy-2-thiouracil
}

\author{
Brajesh Kumara, Abhishek Suman ${ }^{*}$ \\ a Department of Chemistry, National Institute of Technology Patna, Patna, 800005, India \\ b Department of Pharmaceutical Chemistry, Government Pharmacy Institute, Agamkuan, Patna, 800007, India
}

\begin{abstract}
5-carbethoxy-2-thiouracil $\left(\right.$ eitot $\left.\mathrm{H}_{2}\right)$ reacts with $\mathrm{CuX}(\mathrm{X}=\mathrm{Cl}, \mathrm{Br}, \mathrm{I})$ halides to give the formula $\left[\mathrm{CuX}(\mathrm{eitotH})_{2}\right]_{2}$ dinuclear complexes, while the formula $\left[\mathrm{CuX}\left(\mathrm{PPh}_{3}\right)_{2}(\text { eitotH })_{2}\right.$ ] mononuclear mixed ligand complexes result when reaction is carried out in the presence of two equivalent of triphenylphosphine $\left(\mathrm{PPh}_{3}\right)$. The new copper (I) complexes were studied against two tumor cell lines, A549 (human pulmonary carcinoma cell line) and HeLa (human epithelial carcinoma cell line) and one regular immortalized cell line, MRC5 (human fetal lung fibrobla st). In comparison to the phosphine free ones that hindered cell proliferation only at relatively high concentration, the mixed ligand complexes with triphenylphosphine were found to be extremely cytotoxic.
\end{abstract}

Keywords: Copper (I), 5-carbethoxy-2-thiouracil (eitotH 2 ), Triphenylphosphine, in vitro cytotoxicity, carcinoma cell lines

Article Info: Received 07 Sep 2020; $\quad$ Review Completed 28 Oct 2020; $\quad$ Accepted 13 Nov 2020; $\quad$ Available online 01 Dec 2020

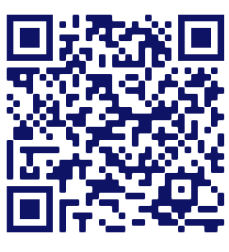

Cite this article as:

Kumar B, Suman A, Synthesis, spectroscopic characterization and biological application of copper complex of 5 carbethoxy-2-thiouracil, Journal of Drug Delivery and Therapeutics. 2020; 10(6):145-148 http://dx.doi.org/10.22270/jddt.v10i6.4417

*Address for Correspondence:

Abhishek Suman, Department of Pharmaceutical Chemistry, Government Pharmacy Institute, Agamkuan, Patna, 800007, India

\section{INTRODUCTION:}

The main biochemical function of copper is well known both as an important trace metal to many metalloenzymes and as a component of exogenously administered compounds in humans, primarily in the complexes that can interact with biomolecules. Numerous copper enzymes and proteins, most of them in their active site possessing a bimetallic copper nucleus, play Important features in biological processes 1 . Therefore, there is a particular interest in bimetallic copper complexes since they can act as templates for a variety of important biological systems. For example, in the biological binding, activation and reduction of dioxygen, the role of dicopper sites in electron transfer processes has been the subject of intensive research over the last two decades $2-5$. Copper complexes are interesting because of their possible use as antimicrobial agents 6-8, anti-inflammatory agents 9,10 antitumor agents 11-14, but copper (II) complexes are most of the studied compounds. Similar studies are less popular on copper(I) derivatives, and the complexes typically contain planar aromatic chelating ligands 15-17 or ligands capable of stabilizing the aqueous media`s low oxidation state of the metal ion.
Orotic acid (6-carboxyuracil) is a biologically very essential molecule and is the only active precursor for nucleic acid production of the pyrimidine bases 18,19 . Orotic acid plus its derivatives and metal complexes have been the focus of extensive studies for the reason 20-23. Differently relatively less consideration has been given its anticancer, antibacterial, and anti-hypertensive properties, isoorotic acid (5-carboxyuracil) 24, 25. Copper complex of isoorotic acid show antibacterial properties, 26 and platinum complex show antibacterial, antiviral and antitumor properties 27.

5-carbethoxy-2-thiouracil prefer the ester contrary to the free 5-carboxy-2-thiouracil we wanted to assure the wellknown coordination of thione-S to the soft copper (I) ion, preventing any potential side effect, such as metal oxidation. 5-carbethoxy-2-thiouracil (eitot $\left.\mathrm{H}_{2}\right)$ has received little attention so far, considering its biological significance 28 , as there are literally no references to its co-ordinating action. The synthesis and characterization of $\left[\mathrm{CuX}\left(\text { eitot } \mathrm{H}_{2}\right)_{2}\right]_{2}$ and [CuX(eitotH $\left.\mathrm{CH}_{2}\left(\mathrm{PPh}_{3}\right)_{2}\right]$ copper (I) halide complexes and the structural characterization of representative compounds of each form are recorded in this work (where eitot $\mathrm{H}_{2}=5$ carbethoxy-2-thiouracil). We also researched the cytotoxic activity of the new compounds against tumor cell lines, A549 
(cell line of human pulmonary carcinoma) and HeLa (cell line of epithelial carcinoma) and one normal immortalized cell line, MRC5 (human foetal lung fibroblast)

\section{EXPERIMENTAL SECTION}

\section{Material for synthesis}

Copper (I) halides, triphenylphosphine and 5-carbethoxy-2thiouracil, commercially available were bought as reagent grade and used as materials, while the solvents were filtered. According to guideline Infra-red spectra with Nicolet FTIR 6700 spectrophotometer were obtained in $\mathrm{KBr}$ discs in the range of $4000-200 \mathrm{Cm}^{-1}$, while a Shimadzu $160 \mathrm{~A}$ spectrophotometer was used to obtain the electronic absorption spectra.

Synthesis of complexes 1-3: A solution of $200.2 \mathrm{mg}$ (1mmol of 5-carbethoxy-2-thiouracil was applied to a a solution of ( $0.5 \mathrm{mmol}$ ) copper (I) halide ( $49 \mathrm{mg}$ for $\mathrm{CuCl}, 71.7$ $\mathrm{mg}$ for $\mathrm{CuBr}, 95.2 \mathrm{mg}$ for $\mathrm{CuI}$ ) in $30 \mathrm{~cm}^{3}$ of dry acetonitrile in $20 \mathrm{~cm}^{3}$ of methanol and the mixture was stirred for $1 \mathrm{~h}$ at ambient temperature. The resulting bright yellow solution was filtered and left to stand in the atmosphere, depositing yellow crystals that was filtered off and vacuum dried.

[CuCl(eitotH $\left.)_{2}\right]_{2}$ (1): Yellow powder (112 mg, 45 \%), m.p. $270^{\circ} \mathrm{C}$; Anal. Calc. For

$\mathrm{C}_{28} \mathrm{H}_{32} \mathrm{Cu}_{2} \mathrm{Cl}_{2} \mathrm{~N}_{8} \mathrm{O}_{12} \mathrm{~S}_{4}:$ C, 33.67; H, 3.23; N, 11.22. Found: C, 33.47; H, 3.12; N, 11.08. IR ( $\left.\mathrm{cm}^{-1}\right): 3119 \mathrm{~m}, 3064 \mathrm{~m}, 2934 \mathrm{~m}$, $1715 \mathrm{vs}, 1747 \mathrm{vs}, 1617 \mathrm{~s}, 1562 \mathrm{vs}, 1464 \mathrm{~s}, 1372 \mathrm{~m}, 1293 \mathrm{~s}$ 1140vs, $1061 \mathrm{~m}, 1010 \mathrm{~m}, 802 \mathrm{~s}, 746 \mathrm{~m}, 584 \mathrm{~s}$; UV-Vis ( $\lambda$ max, log ع): 264 (4.23), 311 (4.37).

[CuBr(eitotH $\left.)_{2}\right]_{2}$ (2): Yellow crystals (207 mg, 70 \%), m.p. $271^{\circ} \mathrm{C}$; Anal. Calc. For

$\mathrm{C}_{28} \mathrm{H}_{32} \mathrm{Cu}_{2} \mathrm{Br}_{2} \mathrm{~N}_{8} \mathrm{O}_{12} \mathrm{~S}_{4}: C, 30.92 ; \mathrm{H}, 2.97 ; \mathrm{N}, 10.30$. Found: $\mathrm{C}$ 31.17; H, 3.03; N, 10.18. IR (cm-1): 3142m, 3050m, 2999m, $1733 \mathrm{vs}, 1622 \mathrm{vs}, 1552 \mathrm{vs}, 1529 \mathrm{vs}, 1460 \mathrm{~s}, 1395 \mathrm{~s}, 1302 \mathrm{vs}$ $1210 \mathrm{vs}, 1145 \mathrm{vs}, 1010 \mathrm{~m}, 886 \mathrm{~m}, 792 \mathrm{~m}, 602 \mathrm{~s}, 510 \mathrm{~m}$; UV-Vis $(\lambda \max , \log \varepsilon): 263$ (4.41), 310 (4.67).

[CuI(eitot $\left.\left.\mathrm{H}_{2}\right)_{2}\right]_{2}$ (3): Yellow crystals (221 mg, 75 \%), m.p. $274^{\circ} \mathrm{C}$; Anal. Calc. For

$\mathrm{C}_{28} \mathrm{H}_{32} \mathrm{Cu}_{2} \mathrm{I}_{2} \mathrm{~N}_{8} \mathrm{O}_{12} \mathrm{~S}_{4}: \mathrm{C}, 28.46 ; \mathrm{H}, 2.73 ; \mathrm{N}$, 9.48. Found: C, 28.55; H, 2.78; N, 9.41. IR $\left(\mathrm{cm}^{-1}\right)$ :

$3129 \mathrm{~m}, 3050 \mathrm{~m}, 2911 \mathrm{~m}, 1733 \mathrm{vs}, 1617 \mathrm{vs}, 1556 \mathrm{vs}, 1524 \mathrm{vs}$, $1460 \mathrm{vs}, 1390 \mathrm{vs}, 1302 \mathrm{vs}, 1210 \mathrm{vs}, 1176 \mathrm{~s}, 1149 \mathrm{vs}, 1010 \mathrm{~m}$, 886m, 866s, 792s, 602vs, 593vs, 514vs; UV-Vis ( $\lambda \max , \log \varepsilon)$ : 264 (3.94), 311 (4.11).

Synthesis of complex 4-6: Copper (I) halide solution $(0.25 \mathrm{mmol})$ (24.5 $\mathrm{mg}$ for copper (I) halide solution in $30 \mathrm{~cm}^{3}$ of dry acetonitrile, triphenylphosphine $(131 \mathrm{mg}, 0.5 \mathrm{mmol})$ was added to $\mathrm{CuCl}, 38.5 \mathrm{mg}$ for $\mathrm{CuBr}, 47.6 \mathrm{mg}$ for $\mathrm{CuI}$, and the solution was stirred until a white precipitate was observed. A solution of $50 \mathrm{mg}(0.25 \mathrm{mmol})$ of 5-carbethoxy-2-thiouracil was added and added to $20 \mathrm{~cm}^{3}$ of methanol. The mixture was stirred at room temperature for $1 \mathrm{hr}$.

[CuCl$\left(\mathrm{PPh}_{3}\right)_{2}\left(\right.$ eitotH $\left.\left.\mathrm{H}_{2}\right)\right] .0 .5 \mathrm{CH}_{3} \mathrm{C}(\mathrm{O}) \mathrm{CH}_{3}$ (4): Yellow crystals (134 mg, $65 \%$ ), m.p. $147^{\circ} \mathrm{C}$; Anal. Calc. For $\mathrm{C}_{43.5} \mathrm{H}_{40} \mathrm{CuClN}_{2} \mathrm{P}_{2} \mathrm{O}_{3.5} \mathrm{~S}: \mathrm{C}, 62.67 ; \mathrm{H}, 4.85 ; \mathrm{N}, 3.28$. Found: C, 62.47; H, 4.82; N, 3.32. IR (cm-1): 3050m, 2984m, 1752vs, $1723 v s, 1695 \mathrm{vs}, 1616 \mathrm{~s}, 1565,1540$ vs, 1480s, 1461vs, $1435 \mathrm{vs}, 1410 \mathrm{~s}, 1369 \mathrm{~s}, 1296 \mathrm{vs}, 1226 \mathrm{vs}, 1147 \mathrm{vs}, 1093 \mathrm{vs}$, $1061 \mathrm{~m}, 1030 \mathrm{~m}, 796 \mathrm{~s}, 742 \mathrm{vs}, 694 \mathrm{vs}, 590 \mathrm{~s}, 517 \mathrm{vs}, 501 \mathrm{vs}$; UVVis $(\lambda \max , \log \varepsilon)$ : 262 (4.48), 310 (4.39).

$\left[\mathrm{CuBr}\left(\mathrm{PPh}_{3}\right)_{2}\left(\right.\right.$ eitot $\left.\left.\mathrm{H}_{2}\right)\right] . \mathrm{CH}_{3} \mathrm{CN}$ (5): Yellow crystals $(173 \mathrm{mg}$, 80 \%), m.p. $154^{\circ} \mathrm{C}$; Anal. Calc. For $\mathrm{C}_{45} \mathrm{H}_{41} \mathrm{CuBrN}_{3} \mathrm{P}_{2} \mathrm{O}_{3} \mathrm{~S}$ : C,
59.44; H, 4.54; N, 4.62. Found: C, 59.17; H, 4.61; N, 4.64. IR $\left(\mathrm{cm}^{-1}\right): 3148 \mathrm{~m}, 3049 \mathrm{~m}, 2936 \mathrm{~m}, 1752 \mathrm{vs}, 1730 \mathrm{vs}, 1619 \mathrm{~s}$, 1566, 1556vs, 1482vs, 1458s, 1435vs, 1407s,

$1367 \mathrm{~s}, 1293 \mathrm{vs}, 1223 \mathrm{vs}, 1150 \mathrm{vs}, 1097 \mathrm{vs}, 1061 \mathrm{~m}, 1026 \mathrm{~m}$, $846 \mathrm{~m}, 745 \mathrm{vs}, 694 \mathrm{vs}, 587 \mathrm{~s}, 517 \mathrm{vs}, 498 \mathrm{vs}$; UV-Vis ( $\lambda \max$, log $\varepsilon): 263$ (4.56), 308 (4.49).

[CuI( $\left(\mathrm{PPh}_{3}\right)_{2}\left(\right.$ eitotH $\left.\left._{2}\right)\right]$ (6): Yellow powder (176 mg, $77 \%$ ), m.p. $191^{\circ} \mathrm{C}$; Anal. Calc. For

$\mathrm{C}_{43} \mathrm{H}_{38} \mathrm{CuIN}_{2} \mathrm{P}_{2} \mathrm{O}_{3} \mathrm{~S}: \mathrm{C}, 56.43 ; \mathrm{H}, 4.18 ; \mathrm{N}, 3.06$. Found: $\mathrm{C}, 56.15$; $\mathrm{H}, 4.10 ; \mathrm{N}, 3.01$. IR $\left(\mathrm{cm}^{-1}\right)$ :

$3050 \mathrm{~m}, 2932 \mathrm{~m}, 1755 \mathrm{vs}, 1736 \mathrm{vs}, 1616 \mathrm{~s}, 1556 \mathrm{vs}, 1477 \mathrm{vs}$, 1457s, 1435vs, 1401s, 139v0s, 1293vs,

$1226 \mathrm{vs}, 1144 \mathrm{vs}, 1093 \mathrm{~s}, 1024 \mathrm{~m}, 886 \mathrm{~m}, 846 \mathrm{~m}, 799 \mathrm{~s}, 742 \mathrm{vs}$, 694vs, 587s, 517vs, 501vs, 489s; UV-Vis ( $\lambda \max , \log \varepsilon$ ): $264 \mathrm{sh}$ (5.11), 309 (4.88).

\section{Spectroscopic analysis: -}

Complex 1-6 electronic spectra, recorded in acetonitrile at room temperature, show two extreme large bands with a maximum of 264 and $310 \mathrm{~nm}$. The high energy band can be used with reference to the absorption spectrum of the uncoordinated 5-carbethoxy-2-thiouracil intraligand transition on the thione ligand are assigned to $\pi \rightarrow \pi^{*}$, while the lower energy band may be considered to be thione originating CT transitions on the thione ligand are assigned to $\pi \rightarrow \pi^{*}$, while the lower energy band may be considered to be a thione originating CT transition at the $\mathrm{C}=\mathrm{S}$ bond 29,30 that may have a partial CT character, as it lies in region where the free ligand absorbs, expressing a free ligand. Small red shift as a result of copper coordination. The absorption due to the intraligand transition within the triphenylphosphine totally overlaps with the high energy band assigned to the intraligand $\pi \rightarrow \pi^{*}$ transition on the 5-carbethoxy-2thiouracil ligand in the compound spectrum 4-6, resulting in a wide band of increased intensity compared to that in the compound 1-3 spectrum.

The FTIR spectrum of compound 1-6 recorded in 4000-25 $\mathrm{cm}^{-1}$ in which characteristic band of 5-carbethoxy-2thiouracil ligand with band shift of $\mathrm{S}$ coordination. The intense bands appear at $1755 \mathrm{~cm}^{-1}$ and $1733 \mathrm{~cm}^{-1}$ in the spectrum of free eitot $\mathrm{H}_{2}$, due to $v(\mathrm{C}=0)$ stretching vibrations, appear slightly shifted to higher energies in the spectra of all complexes. "thioamide I" band, appear at having contributions from $v(\mathrm{C}-\mathrm{N})$ and $\delta(\mathrm{C}-\mathrm{H})$, remains almost unshifted, the very strong band at $1565 \mathrm{~cm}^{-1}$ known as "thioamide I" band, having contributions from $v(\mathrm{C}-\mathrm{N})$ and $\delta(\mathrm{C}-\mathrm{H})$, remains almost unshifted, but the band at $1163 \mathrm{~cm}^{-1}$ assigned to the "thioamide III", which involves major contributions from $v(\mathrm{C}=\mathrm{S})$, appears clearly shifted (by ca. 20 $\mathrm{cm}^{-1}$ ) towards lower energy upon coordination.

\section{MTT cytotoxicity assay:}

The growth inhibitory effect of tumor cell line was assessed by means of MTT assay. By tracking the conversion of 3- $(4,5-$ dimethyl-2-thiazolyl)-2,5-diphenyl-2H-tetrazolium bromide (MTT) to formazan, cell proliferation was assessed. MTT reduction cell is catalyzed by the enzyme mitochondrial dehydrogenase and is thus an indicator of cellular dehydrogenase 31 .

$1 * 10^{4}$ well (A549) and $5 * 10^{3}$ well (HeLa and MRC5) cells were incubated into 96-well plates and treated with various concentration $(5,10,15,20,3040,50,60$ and $120 \mu \mathrm{M}$ of copper complexes and their uncoordinated ligands (5carbethoxy-2-thiouracil and triphenylphosphine) previously dissolved in DMSO after 24 Hours. The cells which are not 
introduced to copper complexes worked as the monitor. Medium removal from each well and replacement with 100 $\mu \mathrm{l}$ of fresh medium and $10 \mu \mathrm{l}$ of MTT $12 \mathrm{Mm}(5 \mathrm{mg} / \mathrm{ml})$ per well was followed by incubation of complexes with cells for 48 hours. After a further brief incubation at $37^{\circ} \mathrm{C}$ for $4 \mathrm{~h}$, before the purple colored formazan product forms, $100 \mu \mathrm{l}$ of $10 \%$ SDS $10 \%-\mathrm{HCl} 0.01 \mathrm{M}$ was applied to the cells and left for 15-18hrs under the same growth conditions.

\section{Cell cultures:}

Human cell lines were cultured in DHEM (Dulbecco`s adaptaed Eagle`s medium) from three separate sources namely A549 (human pulmonary cell line), immortalized MRC5 (human foetal lung fibroblast) and HeLa (human epithelial carcinoma cell line)

\section{RESULT AND DISCUSSION}

\section{Cytotoxic activity}

The antitumor activity of the compounds was estimated by determining their ablity to inhibit tumor cell growth in the culture medium DMEM (Dulbecco Modified Eagle Medium with L-glutamine) complemented by $10 \%$ foetal bovine serum and antibiotic penicillin and streptomycin.

Copper compounds 1-6 and the corresponding free ligands eitot $\mathrm{H}_{2}$ and $\mathrm{PPh}_{3}$ underwent an MTT assay and their cytotoxic properties were investigated against a panel of two tumor cell lines, A549 (human pulmonary carcinoma cell line) and HeLa (cell line of epithelial carcinoma) and one immortalized normal cell line MRC (humh of MTT complex an foetal lung line) Fiberblasting IC values calculated from the dose survival curve obtained after $48 \mathrm{~h}$ of MTT complex solution therapy. In all the cell lines used the free 5carbethoxy-2-thiouracil eitot $\mathrm{H}_{2}$ and triphenylphosphine $\left(\mathrm{PPh}_{3}\right)$ proved to be very ineffective. In particular, $\mathrm{PPh}_{3}$ gave recognizable $\mathrm{IC}_{50}$ values only at higher concentration. On the contrary, all the complexes examined demonstrated a growth inhibitory potency in the micromolar range against the different cell lines.

The three mixed-ligand complexes namely [CuI $\left(\mathrm{PPh}_{3}\right)_{2}\left(\right.$ eitotH $\left.\left._{2}\right)\right], \quad\left[\mathrm{CuBr}\left(\mathrm{PPh}_{3}\right)_{2}\left(\right.\right.$ eitotH $\left.\left._{2}\right)\right]$ were significantly more successful against all cell lines and notable against HeLa cell lines with $\mathrm{IC}_{50}$ values of $2.55 \mu \mathrm{M}, 3.66 \mu \mathrm{M}$ and $3.36 \mu \mathrm{M}$ respectively. Copper complexes of Carbethoxy-2thiouracil are less active towards HeLa, A549 cancer cell line along with MRC5 non-cancerous cell line, triphenylphosphine counterpart (compound 4-6) even at low temperature.

The cytotoxic activity of the three homoleptic copper (I) halide complexes 1-3 is in the order of $\left[\mathrm{CuI}\left(\text { eitotH }_{2}\right)_{2}\right]_{2}>$ $\left[\mathrm{CuBr}\left(\text { eitotH }_{2}\right)_{2}\right]_{2}>\left[\mathrm{CuCl}\left(\text { eitotH }_{2}\right)_{2}\right]_{2}$ with half the minimum inhibitory concentration ( $\mathrm{IC}_{50}$ ) ranging from 45.5-86.6 $\mu \mathrm{M}$ for HeLa to 54.25-89.56 for MRC5 and 41.3-110 for A549.

The values of half the minimum inhitory concentration (IC $\left.{ }_{50}\right)$ are slightly lower, ranging from 2.55-3.6 $\mu \mathrm{M}$ for HeLa 4.776.84 for MRC and 4.56-5.0 for A549, considering the three heteroleptic complexes 4-6. The in vitro cytotoxicity against A549 of all three complexes exceeds that recently recorded for cisplatin by a factor of approximately $2{ }^{32}$. There is no strong pattern in the cell killing effect observed when moving from chlorine to bromo to iodo derivative compared with the case of compound 1-3.

Now a day, Copper complexes examined as a suitable drug for cytotoxicity against tumor cells. ${ }^{33}$. It is well known that phosphine-containing complexes are used as possible anticancer agents 34-36. In most cases, the presence of phosphine in the gold was observed compared to phosphine- free bacteria, thiolates induced increased cytotoxicity. It is known that copper binding compounds are only successful in binding ubiquinated protein accumulation and apoptosis in tumors' but not in nontransformed cells, as other proteasome inhibitors have been identified. The effects of anti-angiogenesis and the possible use of proteasome inhibitors in cancer therapy have been extensively investigated 37,38 . In general, studies involving DNA breakage or copper replacement of copper containing enzymes, ROS development improvement or alteration in copper metabolism need to be conducted. Our observation, however are promising, along with recent research on copper (I) derivatives, as we may consider these new derivatives as lead compounds to discover new potential cancer drugs.

\section{CONCLUSION}

5-carbethoxy-2-thiouracil (eitotH $\mathrm{H}_{2}$ ) co-ordinates to copper (I) halides entirely via the soft thione $\mathrm{S}$ atom forming $\left[\mathrm{CuX}\left(\mathrm{eitotH}_{2}\right)_{2}\right]_{2}$ composition dinuclear complexes with the two metal ions in a highly distorted tetrahedral framework, doubly bridged by atoms of thione Sulphur. These dimers are used to generate mononuclear four coordinate phosphine/ thione as precursors for the preparation of mixed ligand [CuX(eitotH $\left.\left.{ }_{2}\right)\left(\mathrm{PPh}_{3}\right)_{2}\right]$ form complexes. These dimers are used to generate mononuclear four coordinate phosphine/thione as precursors for the preparation of mixed -ligand to form complexes [CuX(eitotH $\left.\left.{ }_{2}\right)\left(\mathrm{PPh}_{3}\right)_{2}\right]$. Evaluation of the outcomes of cytotoxicity indicates that triphenylphosphine is present in complexes 4-6 contribute to a large increase in cytotoxic activity relative to activity of the phosphine-free compounds 1-3. In addition, the cytotoxicity of all the above complexes is in contrast to that of each of the free ligands, higher in all the cell lines that were tested. The remarkable antitumor behavior of $\left[\mathrm{CuCl}\left(\mathrm{PPh}_{3}\right)_{2}\left(\right.\right.$ eitotH $\left.\left.\mathrm{H}_{2}\right)\right]$, $\left[\mathrm{CuIPPh}_{3}\right)_{2}\left(\right.$ eitotH $\left.\left._{2}\right)\right]$, due to the literature data available so far is due to the literature data available so far is due to the $\mathrm{PPh}_{3}$ presence may be considered to be representative of their capacity to induce apoptosis. A

\section{REFERENCES}

1. Kaim W, Rall J, Copper, a "modern bioelement", Angewandte Chemie International Edition English 1996; 35:43-60.

2. Solomon E.I., Sundaram U.M., Mechonkin T.E., Multicopper Oxidases and Oxygenases, Chemical Reviews 1996; 96:25632605.

3. Holland P.L., Tolman W.B., Dioxygen activation by copper sites: relative stability and reactivity of ( $\mu-\eta 2: \eta 2$-peroxo)- and bis $(\mu-$ oxo)dicopper cores, Coordination Chemistry Reviews 1999; 190-192:855-869.

4. Liang H.-C., Dahan M., Karlin K.D., Dioxygen-activating bioinorganic model complexes, Current Opinion in Chemical Biology 1999; 2:168-175.

5. González-Álvarez M., G. Alzuet, J. Borrás, S. García-Granda, J.M Montejo-Bernardo, Structural and functional models for the dinuclear copper active site in catechol oxidases Synthesis, X-ray crystal structures, magnetic and spectroscopic properties of $\mu$ methoxobridged dinuclear copper(II) complexes with $\mathrm{N}$ substituted sulfonamide ligands, Journal of Inorganic Biochemistry 2003; 96:443-451.

6. Chohan Z.H., Pervez H., Rauf A., Scozzafava A., Supuran C.T., Antibacterial $\mathrm{Co}(\mathrm{II}), \mathrm{Cu}(\mathrm{II}), \mathrm{Ni}(\mathrm{II})$ and $\mathrm{Zn}(\mathrm{II})$ complexes of thiadiazole derived furanyl, thiophenyl and pyrrolyl Schiff bases, Journal of Enzyme Inhibition and Medicinal Chemistry 2002; 17:117-122.

7. Sau D.K., R.J. Butcher, S. Chaudhuri, N. Saha, Spectroscopic, structural and antibacterial properties of copper(II) complexes with bio-relevant 5-methyl-3-formylpyrazole N(4)-benzyl-N(4)methylthiosemicarbazone, Molecular and Cellular Biochemistry 2003; 253:21-29.

8. Tsiaggali M., E.G. Andreadou, A.G. Hatzidimitriou, A.A. Pantazaki, P. Aslanidis, Copper(I) halide complexes of Nmethylbenzothiazole-2-thione: Synthesis, structure, 
luminescence,antibacterial activity and interaction with DNA, Journal of Inorganic Biochemistry 2013; 121:121-128.

9. Weder J.E., C.T. Dillon. T.W. Hambley, B.J. Kennedy, P.A. Lay, J.R. Biffin, H.L. Regtop, N.M. Davies, Copper complexes of nonsteroidal anti-inflammatory drugs: an opportunity yet to be realized, Coordination Chemistry Reviews 2002; 232:95-126.

10. Moya-Hernández M.R., A. Mederos, S. Domínguez, A. Orlandini, C.A. Ghilardi, F. Cecconi,E. González-Vergara, A. RojasHernández, Speciation study of the anti-inflammatory drug tenoxicam (Htenox) with $\mathrm{Cu}(\mathrm{II})$ : X-ray crystal structure of [Cu(tenox)2(py)2] EtOH, Journal of Inorganic Biochemistry 2003; 95:131-140.

11. Hindi K.M., M.J. Panzer, C.A. Tessier, C.L. Cannon, W.J. Youngs, The Medicinal Applications of Imidazolium Carbene-Metal Complexes, Chemical Reviews 2009; 109:3859-3884.

12. Bowen R.J., M. Navarro, A.M. Shearwood, P.C. Healy, B.W. Skelton, A. Filipovska, S.J.Berners-Preis, 1:2 Adducts of copper(I) halides with 1,2-bis(di-2-pyridylphosphino)ethane: solid state and solution structural studies and antitumour activity, Daltonon Transactions 2009; 10861-10870.

13. F. Tisato, C. Marzano, M. Porchia, M. Pellei, C. Santini, Copper in diseases and treatments, and copper-based anticancer strategies, Medicinal Research Reviews 2010; 30:708-749.

14. Marzano C, Pellei M, Tisato F, Santini C, Copper Complexes as Anticancer Agents, Anti-Cancer Agents in Medicinal Chemistry 2009; 9:165-211.

15. Reich K.A., L.E. Marshall, D.R. Graham, D.S. Sigman, Cleavage of DNA by the 1,10-phenanthroline-copper ion complex. Superoxide mediates the reaction dependent on NADH and hydrogen peroxide, Journal of the American Chemical Society 1981; 103:3582-3584.

16. Sigman D.S., Nuclease activity of 1,10-phenanthroline-copper ion, Accounts of Chemical Research 1986; 19:180-186.

17. Sigman D.S., Mazumder A, Perrin D.M., Chemical nucleases, Chemical Reviews 1993; 93.

18. Lieberman I, Kornberg A, Simms E.S., Enzymatic synthesis of pyrimidine nucleotides.Orotidine-5'-phosphate and uridine-5'phosphate, Journal of Biological Chemistry 1955; 215:403-415.

19. Victor J, Greenberg L.B., Sloan D.L., Studies of the kinetic mechanism of orotate phosphoribosyltransferase from yeast, Journal of Biological Chemistry 1979; 254:2647-2655.

20. Dodin G, Dubois JE, Tautomerism of Orotic Acid Dianion. Effect of Calcium and Magnesium Cations on the Tautomeric Constant and on Tautomerization Dynamics, Journal of the American Chemical Society 1980; 102:3049-3056.

21. Arrizabalaga P, Castan P. Dahan F, Coordination sites of 5-nitro6-carboxyuracil: UV study and x-ray structure determination of diammine(5-nitroorotato)copper(II) hydrate and hexaamminebis(5-nitroorotato)tricopper(II) pentahydrate, Inorganic Chemistry 1983; 22:2245-2252.

22. Arrizabalaga $P$, Castan P. J.-P. Laurent, Intramolecular influence of a carboxylic function on platinum blue synthesis. A systematic study of complexes originating from acid amides, Journal of the American Chemical Society 1984; 106:4814-4818.

23. Lea M.A., A. Luke, A. Assad, M. Patel, P. Amala Reddy, Inhibitory action of orotate, 2-thioorotate and isoorotate on nucleotide metabolism and nucleic acid synthesis in hepatoma cells, International Journal of Biochemistry 1992; 24:1453-1459.

24. Garoufis A., S.K. Hadjikakou, N. Hadjiliadis, Palladium coordination compounds as antiviral,anti-fungal, anti-microbial and anti-tumor agents, Coordination Chemistry Reviews 2009; 253:1384-1397.

25. Hueso-Urena F., M.N. Moreno-Carretero, J.M. Salas-Peregrin, G.Alvarez de Cienfuegos-Lopez, Palladium, platinum, cadmium, and mercury complexes with neutral isoorotic and 2thioisoorotic acids: IR and NMR spectroscopies, thermal behavior and biological properties, Journal of Inorganic Biochemistry 1991; 43:17-27.

26. Hueso-Urena F., M.N. Moreno-Carretero, J.M. Salas-Peregrin, C. Valenzuela-Calahorro,G.Alvarez de Cienfuegos-Lopez, Thermal, spectral and biological studies or metal complexes of isoorotic and 2-thioisoorotic acids, Thermochimica Acta 1988; 133:341346.

27. Rosenberg B., L. Van Camp, R.G. Fisher, S. Kansy, H.J. Peresie, J.R. Davidson, U.S. Patent No. 4,419,351, 1983.

28. Lea M.A., Luke A, Assad A, Patel M, Reddy PA, Inhibitory action of orotate, 2-thioorotate and isoorotate on nucleotide metabolism and nucleic acid synthesis in hepatoma cells, International Journal of Biochemistry 1992; 24:1453-1459.

29. Kutal C., Spectroscopic and photochemical properties of $d^{10}$ metal complexes, Coordination Chemistry Reviews 1990; 99:213-252.

30. Sharma A., Gupra V, Mishra R, Tandon P, S. Maeda, K.-K. Kunimoto, Study of vibrational spectra and molecular structure of intermolecular hydrogen bonded 2-thiohydantoin using Density Functional Theory, Journal of Molecular Structure 2011; 1004:237-252.

31. Mosmann T., Rapid colorimetric assay for cellular growth and survival: application to proliferation and cytotoxicity assays, Journal of Immunological Methods 1983; 65:55-63.

32. Porchia M., Dolmella A., V. Gandin, C. Marzano, M. Pellei, V. Peruzzo, F. Fefosco, C.Santini, F. Tisato, Neutral and charged phosphine/scorpionate copper(I) complexes: Effects of ligand assembly on their antiproliferative activity, Journal of Medicinal Chemistry 2013; 59:218-226.

33. Griffith D., J.P. Parker, C.J. Marmion, Enzyme Inhibition as a Key Target for the Development of Novel Metal-Based Anti-Cancer Therapeutics, Anti-Cancer Agents in Medicinal Chemistry 2010; 10:354-370.

34. Berners-Price S.J., Sadler P.J., Phosphines and metal phosphine complexes: relationship of chemistry to anticancer and other biological activity, in: Structure and Bonding, Springer, Berlin, 1988.

35. Nazarov A.A., Dyson P.J., Metal Phosphorus Complexes as Antitumor Agents, in: Phosphorus Compounds, Catalysis by Metal Complexes, 37, Springer Science+Business Media B.V., 2011.

36. Tiekink E.R.T., Gold derivatives for the treatment of cancer, Critical Reviews inOncology/Hematology 2002; 42:225-248.

37. Adams J., Development of the Proteasome Inhibitor PS-34, Oncologist 2002; 7:9-16.

38. Dou Q.P., Goldfarb R.H., Bortezomib/PS341 (millennium pharmaceuticals), IDrugs 2002; 5:828-834. 